\title{
Perceptions, expectations, apprehensions and realities of graduating South African optometry students (PEAR study, 2006)
}

\author{
AO Oduntan", A Louw**, VR Moodley ${ }^{\dagger}$, M Richter ${ }^{\dagger \dagger}$ and P Von Poser ${ }^{\dagger \dagger \dagger}$
}

* Department of Optometry, University of Limpopo, Turfloop Campus, Private Bag x1106, Sovenga, 0727 South Africa

** Department of Optometry, Free State University. PO Box 339, Bloemfontein, 9300 South Africa

${ }^{\dagger}$ Department of Optometry, University of Kwazulu-Natal, Private Bag X54001, Durban, 4000 South Africa

${ }^{\dagger}$ University of Johannesburg, Kingsway Campus, PO Box 524, Auckland Park, 2006 South Africa

${ }^{\dagger \dagger \dagger}$ University of Johannesburg, Doornfontein Campus, PO Box 17011, Doornfontein, 2028 South Africa

\begin{abstract}
The objective of this study was to establish the perceptions, expectations, apprehensions and realities of South Africa optometry students completing their undergraduate studies in 2006. Copies of a questionnaire containing relevant information were distributed to all graduating students at the four Universities offering Optometry. The responses were coded and analyzed. The respondents $(N=143)$, representing $77 \%$ of the graduating students included $27.3 \%$ males and $72.7 \%$ females, aged 20 to 37 years (mean $=23.34 \pm 2.75$ ). About a third $(32.9 \%)$ of the respondents considered opening their own practice as the best way of entering into practice. Also, this mode of practice was considered as providing the greatest fulfilment for their personal $(60.8 \%)$ and professional $(53.8 \%)$ goals as well as offering long term financial security $(43.7 \%)$. Many $(56.6 \%)$ have secured employment before graduation. Upon graduation, $43.4 \%$ would like to join a franchise. Many $(79.7 \%)$ felt that Government was not offering sufficient opportunities for optometrists. The majority, $(70.6 \%)$ felt that the South African optometry profession is fastly becoming saturated and this was of great concern to many $(31.5 \%)$. About half, $(50.3 \%)$ have plans to go overseas to practice and the most common destinations were the UK $(36.1 \%)$ and Australia (15\%). The mean minimum monthly salary expected as new graduates was between R9 500 and R11 500 in the public and private sectors respectively. On a response scale, the future of optometry in South Africa was scored as $6.59 \pm 1.92$. Findings in this study may be useful to all stake holders in optometric education in South Africa, as they may reflect the future of the optometry profession in the country.
\end{abstract}

Key words: Perceptions of optometry students, Surveys of optometry students, PEAR study

\section{Introduction}

Optometry education was started in South Africa at the Witwatersrand Technikon in 1931 with the introduction of a part time course. Eventually, the institution offered a four year diploma qualification. This was followed by the University of the North (now University of Limpopo), which started a degree programme in 1975. Subsequently, departments in other institutions were also started: University of Durban Westville (now University of Kwazulu-Natal) (1980), The Rand Afrikaans University (1984) (now the University of Johannesburg) and University of the Free State (2002). All these institutions offer degree

\footnotetext{
* BSc (Hons) Optom PhD

** BOptom CAS (NewEnCO)

$\dagger$ BOptom CAS (NewEnCO) MOptom

$\dagger \dagger$ BOptom CAS (NewEncCO) MPhil

tit DipOptom CAS (NewEnCO)

Revised 14 June 2007; revised version accepted 1 September 2007
} 
programmes. From 2000, the Witwatersrand Technikon offered a four year BTech qualification but this has been discontinued after the merger with the Rand Afrikaans University. These institutions are the only sources of the optometric workforce in South Africa and the neighbouring countries, with a few practitioners entering the profession from outside South Africa.

There have been a series of changes in the academic structures in South Africa which saw the merging of tertiary institutions. The merging of the Witwatersrand Technikon and the Rand Afrikaans University in January 2005 to form the University of Johannesburg has resulted in all the South African optometric qualifications being Bachelor of Optometry degrees. This year (2006), therefore, is a landmark in which South Africa offers Bachelor degrees as the basic optometry qualification.

This survey is the first of its kind, where all South African students graduating with similar qualifications were involved. Also, it is the first study to undertake a nationwide survey of optometry students. Previous surveys of graduating students were carried out at individual institutions ${ }^{1,2}$. In his conclusion, Fine ${ }^{1}$, who reported on the perceptions, expectations and realities of the graduating class of 1995 at Rand Afrikaans University indicated that if the evaluation of the perceptions and expectations are to be of further use, it becomes evident that similar studies should be conducted annually and where necessary expanded and compared with other institutions. This study afforded the students who were about to graduate the opportunity to express their views concerning the educational training that they just completed and their perceptions, expectations and apprehensions of the optometric profession in South Africa.

Currently, the most common mode of practice that graduating students engage in is employment in existing practices. Other options, however, include working in the public sector (Government hospitals), opening one's own practice, buying into an existing practice, buying an existing practice, or joining franchises or academic institutions. The mode of practice that a graduating student will follow depends amongst other factors on personal choice in terms of which option provides the greatest personal and or professional fulfilment. It was considered of interest to establish which of the available mode of practices is most popular with the graduating students as this will influence the future shape of the optometric profile in the country.

According to Sacharowitz ${ }^{3}$, part of the problem facing optometry in South Africa is that the previous government's health policies did not include optometric posts at state or district hospitals. The Department of Health of the Limpopo Province has, however, been employing optometrists since 1991., 4 A summary of the current optometry posts in the public sector is shown in Table 1. In view of the national proposed human resources needed to prevent blindness in South Africa which includes one optometrist per 250000 population $^{5}$ (representing a national total of 160 Optometrists in the public sector), it is anticipated that the number of the optometrists in the public will increase in the near future.

Table 1: A summary of optometrist posts in the public sector in the nine Provinces of South Africa. The Limpopo Province has the highest number of posts. Eastern Cape, North West and Western Cape Provinces are yet to create positions for Optometrists.

\begin{tabular}{|l|l|l|}
\hline \multirow{2}{*}{ Province } & Positions & Vacant \\
\cline { 2 - 3 } & Filled & 43 \\
\hline Limpopo & 31 & - \\
\hline Kwazulu-Natal & 11 & 3 \\
\hline Free State & 6 & 15 \\
\hline Gauteng & 4 & 3 \\
\hline Mpumalanga & 3 & - \\
\hline Northern Cape & 1 & - \\
\hline Eastern Cape & - & - \\
\hline North West & - & - \\
\hline Western Cape & - & \\
\hline
\end{tabular}

In South Africa, as for many developing countries worldwide, health care services are concentrated in the major cities, with little or no services in many rural communities. One of the main reasons for this is the fact that economic opportunities and social amenities are concentrated in the urban areas of the country. For millions of South Africans living in the rural areas, professional eye care is not an option; the most they can 
hope for is treatment by nurses at medical day clinics, and usually this relates to some form of eye injury ${ }^{6}$. The reality, however, is that every citizen should have equal access to eye care services as well as other social amenities. Therefore, one of the purposes of this study was to establish the proportion of the graduating students who would like to practice in the rural areas of the country. The response obtained may provide an indication of future optometric eye care services for rural South Africans.In a study of graduates from the Rand Afrikaans University Department of Optometry, the participants indicated how they fared after graduation ${ }^{7}$. The comments amongst others included that, there were too many graduates or that there were not enough jobs for the graduates. Fine ${ }^{7}$ indicated that many of the conclusions drawn by members of the profession were based on personal feelings and biases. These types of comments on optometric practice in the country can still be heard from optometrists in private practice today. It was considered necessary to evaluate the personal feelings of the graduating students regarding their perceptions of professional opportunities in the country. The feelings of these students may be different as they might not have been exposed to the anecdotal perception that the profession is saturated.

People vary in the way that they absorb information. This variable capacity is evident among students even though they have all attended optometry programmes with similar outcomes. This means that practitioners will vary in their understanding and capacity to apply certain theoretical, practical or businessoriented issues after graduation ${ }^{8}$. This variability may also influence their choice of speciality areas. In view of this, questions were asked regarding which courses that each student was most prepared for or least prepared for to enter into practice. Also, their choice of speciality areas were asked in this study.

Within the past decade or so, compulsory continuing professional development (CPD) has been a contentious issue in many parts of the world ${ }^{9}$ including South Africa. In a study which included aspects of CPD, Fine ${ }^{1}$ found that $51 \%$ of the respondents indicated that CPD should be compulsory and a significant proportion, $49 \%$ indicated that it should not be so. Ethical practice of the health professions requires consistent and ongoing commitment from all concerned to update and develop the knowledge, skill and ethical attitudes that underpin competent practice ${ }^{10}$. This perspective protects the public interest and promotes the health of all members of South African Society ${ }^{10}$. As from 2004, CPD activities have been mandatory for practicing optometrists in South Africa and several activities are available. Although the students in this survey have not been exposed to CPD activities, it was assumed that they were aware of the activities and that they are supposed to partake in them when in practice. It was therefore, considered of interest to ask which CPD activities would be preferable to the students (who naturally have little experience of CPD post-graduation). The responses will be useful to accreditors and service providers as it provides information of the type of CPD would be acceptable to these new generation.

Advertising of optometric services has also been a contentious issue in South Africa in recent years. The Health Professions Council of South Africa (HPCSA) allows advertising of services, provided it is not unprofessional, untruthful, deceptive or misleading. Canvassing (drawing attention, either verbally or by means of printed or electronic media, to one's personal qualities, superior knowledge, quality of service, professional guarantees or best practice ${ }^{11}$ is, however, not allowed. In spite of this, what some might regard as undesirable advertising have been seen on television within the past few years. This may impact on advertising of optometric services in South Africa in the future. It was therefore, considered of interest to ask questions relating to advertising and marketing of optometric services in this study.

\section{Materials and method}

A questionnaire (see Appendix) modified from the one used in a previous study ${ }^{12}$ was used to collect data. The questionnaires were distributed to all graduating students at the four Universities offering Optometry in South Africa, namely the University of Free State, University of Johannesburg, University of Kwazulu-Natal and the University of Limpopo. The information from the questionnaires was coded and subsequently analyzed with the computer programme, Statistical Packages for Social Sciences (SPSS). The data from each institution was analyzed separately. The results of the analyses are discussed and reported in this article. Mostly, the results from all the institutions are discussed together. Where considered necessary, comments are made about some specific results from individual institutions. 


\section{Results}

The total number of respondents was 143 , representing $77 \%$ of the graduating students. The respondents included $39(27.3 \%)$ males and $104(72.7 \%)$ females. The ages are shown in Table 2 and their institutions, gender and race are shown in Table 3. Their ages in relation to gender are shown in Figure 1 and their gender in relation to race is shown in Figure 2. There were more female participants from each institution and over $80 \%$ of the participants from the UJ, UKZN and UFS were females (see Table 3 and Figure 1). Racial distributions of participants in all the institutions (see Table 3 and Figure 2) do not reflect the national populations.

Assuming that there were no restrictions (such as previous commitment to an organization) and the students could enter practice in any manner that they wished, $32.9 \%$ considered opening their own practices to be the best way of entering practice. These included $46.2 \%$ of the male and $27.9 \%$ of the female respondents. Other choices are shown in Table 4.

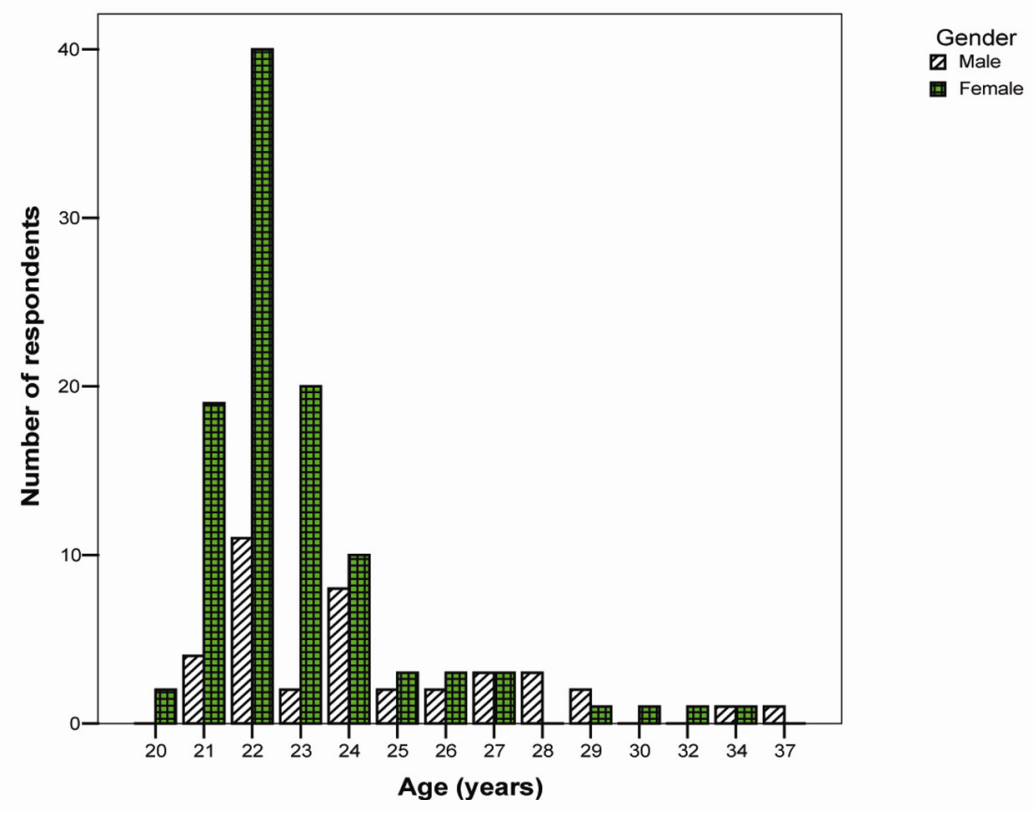

Figure 1: Showing the ages of the respondents in relation to their gender. The ages ranged from 21 to 37 years for males and 20 to 34 years for females. The most common age was 22 years for both males and females.

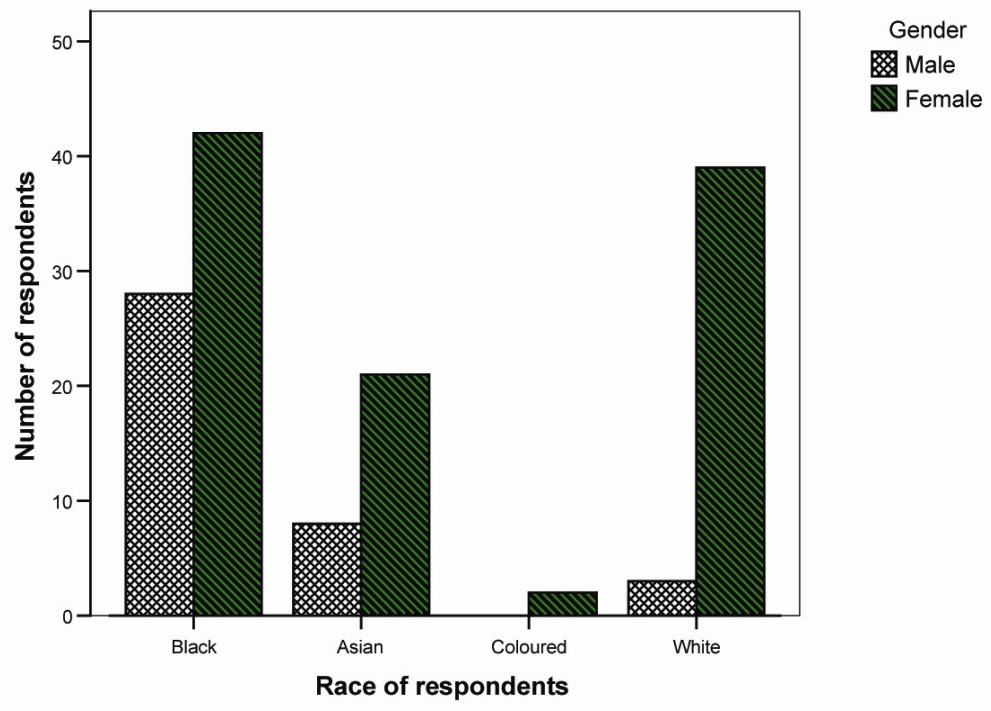

Figure 2: Showing the racial distributions of the respondents. Blacks were more numerous than other racial groups, while coloureds were least common. 
Table 2: Showing the institutions, number of participants $(\mathrm{N})$, and ages of the participants).

\begin{tabular}{|l|l|l|l|}
\hline Institution & $\mathbf{N}$ & $\begin{array}{l}\text { Age range } \\
\text { (years) }\end{array}$ & $\begin{array}{l}\text { Mean } \\
\text { (years) }\end{array}$ \\
\hline UL & 48 & 20 to 37 & $24.56 \pm 3.69$ \\
\hline UJ & 60 & 21 to 28 & $22.85 \pm 1.68$ \\
\hline UKZN & 22 & 20 to 26 & $22.23 \pm 1.54$ \\
\hline UFS & 13 & 21 to 32 & $23.00 \pm 2.94$ \\
\hline Total & 143 & 20 to 37 & $23.34 \pm 2.75$ \\
\hline
\end{tabular}

Based on the current financial remuneration to employees, many respondents $(44.1 \%)$ believed that the most advantageous way to enter practice at the present time is to join a franchise. The distributions of their responses are shown in Table 5. Many (60.8\%) of the respondents felt that the most likely mode of practice that will provide the greatest fulfilment for their personal goals within the next ten years is opening their own practices. This included $71.8 \%$ of the male and $56.7 \%$ of the female samples (see Table 6 ).

Table 3: Showing the institutions, number of participants, their gender and races: Blacks (B), Asians (A), Coloured (C), and Whites (W). Blacks dominated at UL, Whites at UJ and UFS and Asians at UKZN.

\begin{tabular}{|l|l|l|l|l|l|l|l|}
\hline \multicolumn{2}{|l|}{ Institution } & N & \multicolumn{6}{l|}{ Gender \%) } & \multicolumn{4}{l|}{ Race (\%) } \\
\hline & & M & F & B & A & C & W \\
\hline UL & 48 & 47.9 & 52.1 & 95.8 & 2.1 & 0 & 2.1 \\
\hline UJ & 60 & 16.7 & 83.3 & 21.7 & 25.0 & 1.7 & 51.7 \\
\hline UKZN & 22 & 18.2 & 81.8 & 36.4 & 59.1 & 0 & 4.5 \\
\hline UFS & 13 & 15.4 & 84.6 & 23.1 & 0 & 7.7 & 69.2 \\
\hline Total & 143 & 27.3 & 72.7 & 49.0 & 20.3 & 1.4 & 29.4 \\
\hline
\end{tabular}

Table 4: Modes of practice considered to the best way of entering practices, number/ percentage of respondents and within gender percentages

\begin{tabular}{|l|l|l|l|l|}
\hline Mode of practice & No. & $\mathbf{\%}$ & M (\%) & F (\%) \\
\hline Open own practice & 47 & 32.9 & 46.2 & 27.9 \\
\hline Buy into existing practice. & 37 & 25.9 & 25.6 & 26.0 \\
\hline Join Franchise & 30 & 21.0 & 12.8 & 24.0 \\
\hline Join Hospital & 12 & 8.4 & 10.3 & 7.7 \\
\hline Buy existing practice & 11 & 7.7 & 5.1 & 8.7 \\
\hline Join University & 6 & 4.2 & 0 & 5.8 \\
\hline
\end{tabular}

Table 5: Modes of practice considered to be more advantageous to enter practice. Number, percentage of respondents and within gender percentages are shown.

\begin{tabular}{|l|l|l|l|l|}
\hline Mode of practice & No. & $\mathbf{\%}$ & M (\%) & F (\%) \\
\hline Join Franchise & 63 & 44.1 & 23.1 & 51.9 \\
\hline Buy into existing practice & 30 & 21.0 & 15.4 & 23.1 \\
\hline Join Hospital & 28 & 19.6 & 28.2 & 16.3 \\
\hline Open own practice & 15 & 10.5 & 23.1 & 5.8 \\
\hline Join University & 5 & 3.5 & 7.7 & 1.9 \\
\hline Buy existing practice & 2 & 1.2 & 2.6 & 1.0 \\
\hline
\end{tabular}


Table 6: Type of practice (which is likely to provide the greatest fulfilment for personal goals within the next decade), number, percentages and gender percentages

\begin{tabular}{|l|l|l|l|l|}
\hline Mode of practice & No. & $\mathbf{\%}$ & M (\%) & F \%) \\
\hline Open own practice & 87 & 60.8 & 71.8 & 56.7 \\
\hline Buy into existing practice & 17 & 11.9 & 5.1 & 14.4 \\
\hline Franchise & 11 & 7.7 & 7.7 & 7.7 \\
\hline Buy existing practice & 9 & 6.3 & 2.6 & 7.7 \\
\hline Hospital & 9 & 6.3 & 7.7 & 5.8 \\
\hline Join University & 9 & 6.3 & 5.1 & 6.7 \\
\hline
\end{tabular}

Many of the respondents $(53.8 \%)$ felt that the most likely mode of practice that will provide the greatest fulfilment for their professional goals within the next ten years is opening their own practice. This included $64.1 \%$ of the males and $50 \%$ of the females (see Table 7). When asked which of the listed modes of practice will provide the best long term financial security, $42.7 \%$ chose opening their own practices. Other options are shown in Table 8.

Table 7: Showing the most likely mode of practice that will provide the greatest fulfilment for their professional goal within the next ten years. Opening one's own practice was the most common choice and joining franchises is the least common choice.

\begin{tabular}{|l|l|l|l|l|}
\hline Mode of practice & No. & \% & M (\%) & F (\%) \\
\hline Open own practice & 77 & 53.8 & 64.1 & 50 \\
\hline Buy into existing practice & 18 & 12.6 & 10.3 & 13.5 \\
\hline Join University & 17 & 11.9 & 12.8 & 11.5 \\
\hline Join Hospital & 15 & 11.2 & 7.7 & 12.5 \\
\hline Buy existing practice & 9 & 6.3 & 0 & 8.7 \\
\hline Join Franchise & 5 & 3.5 & 5.1 & 2.9 \\
\hline
\end{tabular}

When asked the type of practice that they wish to enter upon graduation, $43.4 \%$ indicated joining a franchise. Other responses are shown in Table 9. If a loan was made available to assist them in obtaining a practice, many $(62.9 \%)$ would prefer buying an existing practice rather than opening a new practice. These included $46 \%$ of the males and $69.2 \%$ of the females. The major reason given for this choice was ' $g o o d$ will' $(50.3 \%)$. A significant proportion $(28.7 \%)$ did not provide a reason for their choice.

Table 8: Number and gender of respondents who felt that each of the listed modes of practice would provide the best long term financial security.

\begin{tabular}{|l|l|l|l|l|}
\hline Mode of practice & No. & \% & M (\%) & F (\%) \\
\hline Open own practice & 61 & 42.7 & 43.6 & 42.3 \\
\hline Join Franchise & 26 & 18.2 & 15.4 & 19.2 \\
\hline Join Hospital & 26 & 19.2 & 28.2 & 14.4 \\
\hline Buy into existing pract. & 21 & 14.7 & 7.7 & 17.3 \\
\hline Buy existing practice & 5 & 3.5 & 0 & 4.8 \\
\hline Join University & 4 & 2.8 & 5.1 & 1.9 \\
\hline
\end{tabular}


Many of the participants (56.6\%) had secured employment for the following year (2007). Those who had secured employment included $53.8 \%$ of the males and $57.7 \%$ of the females. The areas of optometric practice that the respondents felt least prepared for varied widely and included contact lenses $(26.6 \%)$,

dispensing (23.8\%), binocular vision $(21.7 \%)$, ocular pathology $(14.0 \%)$ and low vision (4.2\%). Eight respondents $(5.6 \%)$ reported that there were no areas for which they felt unprepared. Also, the areas of optometric practice that they felt most prepared for varied and included contact lenses $(28.0 \%)$, clinical optometry (22.4\%), ocular pathology $(14.0 \%)$, binocular vision $(11.9 \%)$, dispensing $(10.5 \%)$, low vision and paediatric optometry $(2.8 \%)$ each and environmental Optometry $(0.7 \%)$. One respondent $(0.7 \%)$ reported all. Nine students $(6.3 \%)$ did not respond to this question.

Table 9: Number, percentages and genders of respondents who would join each mode of practices listed.

\begin{tabular}{|l|l|l|l|l|}
\hline Mode of practice & No. & $\mathbf{\%}$ & M (\%) & F (\%) \\
\hline Join Franchise & 62 & 43.4 & 17.9 & 52.9 \\
\hline Buy into existing practice & 32 & 22.4 & 25.6 & 22.1 \\
\hline Join Hospital & 23 & 16.1 & 25.6 & 11.5 \\
\hline Open own practice & 18 & 12.6 & 25.6 & 7.7 \\
\hline Buy existing practice & 7 & 4.9 & 5.1 & 4.8 \\
\hline Join University & 1 & 0.7 & 0 & 1 \\
\hline
\end{tabular}

Many (58.7\%) felt that they have received adequate information in the optometry management courses regarding the various modes of practice that will be available to them on graduation. Three (2.1\%) did not respond to this question. Many $(62.2 \%)$ felt that they have received adequate information in their practice management courses regarding the effects of various modes of practices on their professional/personal life and future. One $(0.7 \%)$ did not respond to this question.

A large proportion $(69.2 \%)$ would prefer to practice in urban areas and $30.1 \%$ would like to practice in rural areas. One student $(0.7 \%)$ did not respond to the question. Those who would like to practice in the urban areas included $59.0 \%$ of the males and $73.1 \%$ of the females. The most common reasons for preferring urban area were convenience or nearness to home (14.0\%) and accessibility (7.7\%). Those who would like to practice in the rural areas were $38.5 \%$ of the males and $26.9 \%$ of the females. The most common reason given by this group was opportunity to offer services to the needy $(12.6 \%)$. Among those who preferred urban practice, the favourite cities were Johannesburg (23.1\%), Pretoria (19.6\%), Cape Town (19.6\%), Durban (14.0\%) and Nelspruit (4.2\%).

Table 10: The range, mean and standard deviation of the monthly salary that the respondents consider to be appropriate for a newly qualified optometrist employed in the public sector

\begin{tabular}{|l|l|l|l|}
\hline \multirow{2}{*}{ Institution } & \multicolumn{3}{|c|}{ Amount (Rand) } \\
\cline { 2 - 4 } & Range & mean & SD \\
\hline UL & $6000-13000$ & 9093.75 & 1579.98 \\
\hline UJ & $6000-15000$ & 9758.93 & 1626.46 \\
\hline UKZN & $7000-16000$ & 10277.78 & 2624.67 \\
\hline UFS & $8000-13000$ & 9384.62 & 1502.14 \\
\hline
\end{tabular}

When asked whether they feel that the South African optometry profession is becoming saturated, a vast majority (70.6\%) reported 'yes' and 14.7\% reported 'no', while others (14.7\%) did not respond to this question. The respondents were divided on whether they felt that the private or the public sector has greater advantages for a recently graduated optometrist. About half $(49.7 \%)$ felt that the private sector has greater advantages and $48.9 \%$ felt that the public sector has greater advantages. Two (1.4\%) did not respond to this question. 
In response to whether they think that the government offers sufficient opportunities for optometrists, $19.6 \%$ reported 'yes', but the majority (79.7\%) reported 'no'. One $(0.7 \%)$ did not respond to the question. Considering the current economic status in South Africa, many of the respondents were of the opinion that the minimum monthly salary for a newly qualified optometrist in the public sector should range from R6 000 to R16 000 with a mean of R9 $555.56 \pm$ R1 789.96 and for the private sector should range from R7 500 to R20 000 (mean = R11 $377.20 \pm$ R2 459.66). From each institution, the distributions of the expected remunerations from the public and private sectors are shown in Tables 10 and 11 respectively.

Table 11: The range, mean and standard deviation of monthly salaries that the respondents consider to be appropriate for a newly qualified optometrist emp'cyed in the private sector.

\begin{tabular}{|l|l|l|l|}
\hline \multirow{2}{*}{ Institution } & \multicolumn{3}{|c|}{ Amount (Rand) } \\
\cline { 2 - 4 } & Range & mean & SD \\
\hline UL & $8000-17255$ & 11353.54 & 2457.88 \\
\hline UJ & $7500-20000$ & 11607.14 & 2358.19 \\
\hline UKZN & $9000-20000$ & 11722.22 & 3227.73 \\
\hline UFS & $8000-12000$ & 10000.00 & 1080.12 \\
\hline
\end{tabular}

Table 12: Showing the benefits that the respondents think an optometrist should get when employed in an existing practice. The most common choice is medical aid.

\begin{tabular}{|l|l|l|}
\hline Benefit & No. & \% \\
\hline Life insurance & 103 & 24.8 \\
\hline Medical aid & 128 & 30.8 \\
\hline Subscription fees & 63 & 15.2 \\
\hline CPD fee & 61 & 14.7 \\
\hline Vacation & 59 & 14.2 \\
\hline Others specified & 1 & 0.2 \\
\hline
\end{tabular}

Table 13: The countries where the respondents would like to go and practice. Many of them prefer the United Kingdom (UK). 'Others' in the table refer to Dubai, Germany, Namibia and Ireland.

\begin{tabular}{|c|c|c|c|c|}
\hline Country & No. & $\%$ & $\begin{array}{l}M \\
\text { N (\%) }\end{array}$ & $\begin{array}{l}\mathbf{F} \\
\mathbf{N}(\%)\end{array}$ \\
\hline UK & 22 & 36.1 & $3(13.6)$ & $19(86.4)$ \\
\hline Australia & 9 & 14.8 & $2(22.2)$ & $7(77.8)$ \\
\hline Caribbean Islands & 9 & 14.8 & $3(33.3)$ & $6(66.7)$ \\
\hline USA & 8 & 13.1 & $1(12.5)$ & $7(87.5)$ \\
\hline Canada & 4 & 6.6 & $0(0)$ & $4(100)$ \\
\hline New Zealand & 3 & 4.9 & $0(0)$ & $3(100)$ \\
\hline Netherlands & 2 & 3.3 & $1(50)$ & $1(50)$ \\
\hline Others & 4 & 6.6 & $0(0)$ & $4(100)$ \\
\hline
\end{tabular}

When asked whether they would like to establish a practice in a mall or in an office setting, $61.5 \%$ responded that they would prefer to establish in a mall rather than in an office setting. The most common reason given by those who prefer the mall was easy accessibility to patients $(49.0 \%)$ and the most common reason offered by those who prefer office setting was that it is more professional $(16.8 \%)$. 
Table 14: The speciality areas of Optometry that the respondents indicated that they were interest in.

\begin{tabular}{|l|l|l|l|l|}
\hline Speciality & No. & \% & $\begin{array}{l}\text { M } \\
\text { N (\%) }\end{array}$ & $\begin{array}{l}\text { N (\%) } \\
\text { Contact lenses }\end{array}$ \\
\hline Sports vision & 27 & 18.9 & $13(48.1)$ & $14(51.9)$ \\
\hline Paediatric optometry & 19 & 13.3 & $1(5.3)$ & $18(94.7)$ \\
\hline Binocular vision & 19 & 13.3 & $7(36.8)$ & $12(63.2)$ \\
\hline Low vision & 14 & 9.8 & $2(14.3)$ & $12(85.7)$ \\
\hline (Others) & 6 & 4.2 & $3(50)$ & $3(50)$ \\
\hline
\end{tabular}

In response to whether they personally think that it is right for optometric practices to advertise through the media such as television, radio, magazines and newspapers, $51.7 \%$ reported 'no', $48.3 \%$ reported 'yes'. The most common reasons given by those who reported 'no' was that 'it lowers the status of the profession (36.5\%) and 'unfair competition' (36.5\%). The most common reason given by those who reported 'yes' was that it affords opportunity to reach those in need of optometric services $(50.7 \%)$.

On whether they think that the public is educated enough about optometry to be able to appreciate the true value of advertised offers such as 'buy one get one free', a large proportion (80.8\%) reported 'no', $14.6 \%$ reported 'yes, and $4.6 \%$ did not respond to the question. On whether they feel that continuing professional development (CPD) activities will enhance their professional activities, $91.5 \%$ reported 'yes', $6.9 \%$ reported 'no' others $1.5 \%$ did not respond.

The CPD activities that they would prefer to participate in after graduation include conferences $(29.3 \%)$, lectures $(27.3 \%)$, internet $(27.1 \%)$ and papers and posters at conferences $(10.3 \%)$. The benefits that they think an optometrist should get when employed in an existing practice are shown in Table 12.

In response to whether at any time during their optometry studies, they felt that they should have studied another course rather than optometry, $45.5 \%$ reported 'yes', $53.1 \%$ reported 'no' and $1.4 \%$ did not respond. The most common courses listed by those who reported 'yes' were medicine (16.9\%), pharmacy $(6.1 \%)$ and accounting $(6.1 \%)$.

When asked whether they have any plans to leave South Africa and practice overseas, 63 (44.1\%) reported 'no', $72(50.3 \%)$ reported 'yes' and $8(5.6 \%)$ did not respond. Those who had plans to practice overseas were predominantly females, being $51 \%$ of the females and $25.6 \%$ of the males. The distribution of choice of countries is shown in Table 13. The probable duration indicated by those who plan to leave South Africa were, short time ( 2 years or less) $27(42.9 \%)$, long time (3-10 years) $10(15.9 \%)$ and permanently 6 (9.5\%). Others, $20(31.8 \%)$ could not decide yet on the duration.

The greatest concerns that the participants had about the optometric profession in South Africa were market saturation $(31.5 \%)$, poor blindness prevention programmes $(3.8 \%)$, narrow scope of practice $(3.8 \%)$ and the exploitation of patients (high cost of eye care) (3.8\%). On a ten-point scale (where 1 is very negative and 10 is very positive), the mean score of the participants $(N=139)$ regarding the future of optometry in South Africa was $6.59(\mathrm{SD}= \pm 1.92)$.

The speciality interests that the respondents would like to follow are shown in Table 14. The area of contact lenses was the most common choice. 'Others' in Table 14 refers to ocular pathology, environmental optometry, prosthetics, and dispensing.

\section{Discussion and Conclusion}

Graduating students usually have certain perceptions, expectations and apprehensions of the new life that they are about to enter into. Many of these are real, others, however, are just personal views. Whether real or personal, it is necessary for educators to ascertain the perceptions, expectations and apprehensions of their students. This will help to better prepare the students, ease their fears where indicated and promote the quality of the programme. 
The aspect that many (79.8\%) of the participants in this study were aged 21-24 years (Figure 1) is good for the profession as these new members would be able to spend at least 40 years of their lives in the profession before they retire. Females were more numerous than males among the participants (see Table 3 and Figure 2). It will be of interest to see how this gender proportion changes in the near future. As shown in Table 3 and Figure 2, the racial distribution of the students' is not fully reflective of the distribution of the national population and this applies to all the departments of optometry. Again, this needs to be addressed by the individual institutions so that equitable racial distribution can be achieved. Possibly, the Professional Board of Optometry and Dispensing Opticians should undertake a national human resource audit and guide institutions on issues of equity. Although opening own practices was considered the best way of entering practice (Table 4), having the likelihood of providing the greatest fulfilment for both personal (Table 6) and professional goals (Table 7) as well as providing the best long term security (Table 8); when their current financial situations were taken into consideration, however, $44.1 \%$ of the respondents considered joining franchises to be more advantageous (Table 4). This may be because perhaps they believe the franchises offer better remuneration and greater security. Also, young graduates generally feel insecure about venturing on their own early in their careers. This probably is the reason why 'franchises' was the type of practice that many (43.4\%), wished to enter upon graduation (see Table 9).

It is quite expected that the students listed varied areas of optometry for which they felt least prepared. This is because each of them has his or her area/s of weakness. An interesting finding, however, was that contact lenses $(26.6 \%)$ was the area of optometry which the students felt least prepared for, but $28 \%$ of the students felt that it was the area that they were most prepared for. This dichotomy in their perception of preparedness for contact lens practice could only be explained by institutional factors. It is possible that those from one or two institutions were well grounded in contact lenses while, those in others were not well prepared. This, however, was not investigated.

It is perhaps of concern that only $58.7 \%$ of the respondents reported that they have received adequate information in the optometric practice management courses with regard to the various modes of practice that are available to them on graduation. Also, only $62.2 \%$ reported having received adequate information in the practice management courses regarding the effects of various modes of practice on their professional/ personal life and future. These suggest the need for greater attention in these areas of the optometric practice management curriculum.

Women have been considered to be more risk averse than men; this appears to be so even when decisionmakers of both genders have the same level of expertise and experience ${ }^{13}$. This attitude was shown in the present study as females showed less likelihood of opening their own practice than males (Tables 4-9). Even if loans were made available to assist them in obtaining a practice, most females (62.9\%) would prefer buying an existing practice rather than opening a new practice.

Disproportionate distribution of optometry services in the rural areas as is currently the case in South Africa and many parts of the developing world does not provide equal opportunity for patients. Obviously, this is undesirable as everybody should have equal access to eye care irrespective of economic status. Many, $69.2 \%$ of the respondents in this survey preferring to practice in an urban area suggest that this problem would persist in South Africa for some time, unless active steps are taken to encourage practitioners into rural areas. Perhaps, some form of incentives from the Government for those in the public sector would attract practitioners into rural areas. This should be looked into otherwise the eye care services needed to prevent visual impairment and blindness in the rural areas will never be realized. The anecdotal perception among practitioners and students that the South African Optometry profession is becoming saturated was also expressed in this survey as $70.6 \%$ of the participants felt that the market was becoming saturated. Also, $31.5 \%$ of the participants considered this to be their greatest concern about optometry profession in South Africa. The reality, however, is that optometry practices are crowded only in the urban areas. A large proportion of South Africa is rural and most areas are without eye care services. If practitioners opt for rural areas, there are still good opportunities in the country. Over half $(56.6 \%)$ of the students have secured employment even before they graduated. This supports the view that the profession is not saturated.

Although respondents were divided on whether the private or public sector offers greater advantages to newly graduated optometrists, many, however, felt that the government is not offering enough opportunities to optometrists. This is obviously true as the optometry positions in most hospitals in the country are limited 
and there are Provinces such as Northern and Western Cape where there are no optometry positions in the public sector as yet (see Table 1). The South African Optometric Association, other non governmental organizations and Optometry institutions need to urge the government to create more positions in the public sector.

Financial remuneration is an important consideration in taking up employment. The mean salary of about R11 000 and R10 000 in the private and public sectors respectively recommended by the participants are higher than what is currently being offered. It is necessary for employers in the private and public sectors to be aware of these expectations. Also, it will be of interest to know what employers will be willing to pay.

Optometry, like Medicine and Dentistry is a health care service rather than retail service; therefore some people may consider the location of practices in shops and malls as not reflecting the health care status of the profession. Many of the students in this study preferring to establish practices in shops rather than office settings suggests that the current trend in which many practices are located in shops will persist for some time.

More respondents $(53.8 \%)$ felt that it is not right for optometry practices to advertise through media such as television, radio and news-papers because it is not ethical. This is a positive response and it is recommended that optometric management courses should emphasize this. The overwhelming respondents $(80.8 \%)$ felt that the public is not educated enough to be able to appreciate the true value of advertisement such as 'buy one spectacle and get one free'. This suggests the need for public awareness campaign in this area otherwise they would continue to be attracted by such adverts.

Commitment to life-long learning should be one of the attributes of optometry students because of the dynamics of the courses involved in the programme. This is one of the reasons why continuing education has been introduced in many parts of the world including South Africa. Commitment to long-life learning via CPD is becoming a part of optometry profession in South Africa. Majority (91.5\%) of the respondents reporting that CPD activities will enhance their professional development is a positive response and is good for the optometric practice in South Africa. This is an obvious change in view compared to the previous findings ${ }^{1,2}$ on this issue. Conference attendance was the most common type of CPD activities that was preferred by the respondents. Information on the CPD activity preference presented in this article will be useful to those who are planning to provide CPD activities. It will be of interest to know whether they still feel this way in the next few years when they have had knowledge of the costs of the various CPD options.

The most popular benefits that the participants felt that employed optometrists should get are presented in Table 12. The most popular being medical aid and life insurance. It will be of interest to establish what benefits the employers would be willing to offer.

At one time or another during a course, a student may contemplate changing to other courses as a result of frustration from the current course or interests in other courses. Many of the participants in the present study have contemplated studying other courses including medicine, pharmacy and accounting. This may among other reasons be because optometry has received some negative publicity over the years, as well as the perception that these other professions may offer greater financial security. It will be of interest to know what their views would be after spending some years practicing optometry.

About half $(50.3 \%)$ of participants in this study had plans to move overseas to practice either temporarily or permanently. This is not good for optometry in South Africa. Presumably, practitioners are going abroad in search of better remuneration. If remuneration in South Africa can be improved, it is possible that this will discourage people from going abroad. Also, other reasons such as the perception of crime level may be responsible for practitioners going abroad. These were however, not established.

The perception of the participants regarding the future of Optometry in South Africa is good (mean = 6.59), indicating that many of them have a good perception of optometry practice in the country. If their areas of concern can be addressed, it is possible that the going abroad to practice may be reduced in the future. The speciality interests that were reported by the respondents vary widely and include contact lenses (37.1\%), sports vision (18.9\%) and binocular vision $(13.3 \%)$. This information will be useful for the institutions that may wish to provide further education in speciality areas in optometry in the future. 


\section{Acknowledgement}

Assistance of Mr Makgaba NT in the analysis of the data is acknowledged. We wish to extend our gratitude to the students who completed to questionnaires.

\section{References}

1. Fine LE. Perceptions, expectations and realities of the graduating class of 1995 at Rand Afrikaans University, Department of Optometry. S Afr Optom 199756 6-14.

2. Oduntan AO. The Optometry Programme at Turfloop as perceived by the 1997 graduating class. S Afr Optom 1999 58 80-87.

3. Sacharowitz HS. Visual impairment in South Africa: Achievements and challenges. S Afr Optom 2005 64 139-149.

4. Oduntan AO, Raliavhegwa M. An evaluation of the impact of the eye care services delivered to the rural communities in the Mankweng Health Sub-District of the Northern Province. S Afr Optom 200160 71-76.

5. Department of Health, Directorate for chronic diseases, disabilities and geriatrics. National guideline for prevention of blindness in South Africa, 2002.

6. Hutchison G. Democratic change. Optician 1995209 26-27.

7. Fine LE. Trends in demographics of optometry students of Rand Afrikaans University. S Afr Optom 1996 6-15.

8. Oduntan AO. Thirty years of optometric education at Turfloop (1975-2005): A historical and educational overview. $S$ Afr Optom 200665 34-40.

9. Vingrys A. Continuing professional education. Clin Exp Optom 199578 138-143.

10. Health Professions Council of South Africa (HPCSA). Continuing professional development guidelines for the Health professions. August, 2006 1-6.

11. Health Professions Council of South Africa. Health Professions Act No. 56 of 1974. Gov. Gazette pages 24-28, August 2006.

12. Silverman WS, Woodruff C, Hardigan PC. The future of Optometric practice? The results of a survey of optometrists and optometry students. Optometry 200475 615-623.

13. Olsen RA, Cox CM. The influence of gender on the perception and response to investment risk: The case of professional investors. J Psych Financial Markets 20012 29-36. 


\section{Appendix}

\section{Questionnaire}

Dear Student,

This survey is being conducted in the various Universities offering optometry in South Africa, to establish the perceptions, expectations and apprehensions of the graduating students regarding optometric practice in this country. Please, complete the questionnaire sincerely and to the best of your knowledge. Write the corresponding number of your answer in the box on the right side of the table or complete as directed.

\begin{tabular}{|l|l|l|}
\hline 1 & $\begin{array}{l}\text { Institution where graduating: UL [1] } \\
\text { UJ: Doornfontein campus [2], Kingsway campus [3] } \\
\text { UKZN [4] UFS [5] }\end{array}$ & $\square$ \\
\hline 2 & Age (years). (Write your age in the box) & $\square \square$ \\
\hline 3 & Gender: M [1] F [2] & $\square$ \\
\hline 4 & Race: African [1] Asian [2] Coloured [3] White [4] & $\square$ \\
\hline
\end{tabular}

N.B. For questions 5-10, please select the most suitable

answer from the following list.

Open your own practice

Buy into an existing practice

Buy an existing practice

Join a franchise

Join Government Hospital

Join an academic institution

(University)

\begin{tabular}{|c|c|c|}
\hline 5. & $\begin{array}{l}\text { Assuming that you have no restrictions and could enter practice in any manner you wished, } \\
\text { what do you consider to be the best way for you to enter practice? }\end{array}$ & \\
\hline 6. & $\begin{array}{l}\text { Based on your current financial situation, which type of practice do you believe would be } \\
\text { most advantageous for you at the present time? }\end{array}$ & 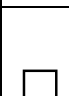 \\
\hline 7. & $\begin{array}{l}\text { Which of the above do you think would be most likely to provide the greatest fulfilment for } \\
\text { your personal goal within the next ten years? }\end{array}$ & L \\
\hline 8. & $\begin{array}{l}\text { Which of the above, do you think would be most likely to provide the greatest fulfilment for } \\
\text { your professional goal within the next ten years? }\end{array}$ & $\square$ \\
\hline 9. & Which of the above do you think would provide the best long-term financial security? & \\
\hline 10. & Which type of practice do you plan to enter upon graduation? & $\square$ \\
\hline 11 & Have you secured employment for next year? Yes [1] No [2] & \\
\hline 12. & $\begin{array}{l}\text { Which area of optometric practice do you feel LEAST prepared for? (e.g. Contact lenses, } \\
\text { binocular vision, dispensing, ocular pathology etc.) ..................... }\end{array}$ & \\
\hline 13. & $\begin{array}{l}\text { Which area of optometric practice do you feel MOST prepared } \\
\text { for?............................................... }\end{array}$ & \\
\hline
\end{tabular}




\begin{tabular}{|c|c|c|}
\hline 14. & $\begin{array}{l}\text { Do you feel you have received adequate information in the optometry management courses } \\
\text { regarding the various mode of practice that will be available to you on graduation? } \\
\text { Yes [1] No [2] }\end{array}$ & $\square$ \\
\hline 15. & $\begin{array}{l}\text { Do you feel you have received adequate information in your practice management courses } \\
\text { regarding the effects of various modes of practices, on your professional/personal life and } \\
\text { future? } \quad \text { Yes [1] } \quad \text { No [2] }\end{array}$ & $\square$ \\
\hline 16. & $\begin{array}{l}\text { If a loan is made available to assist you obtaining a } \\
\text { practice, which of these will you consider? } \\
\qquad \text { Opening a new practice } \\
\text { Buying an existing practice }\end{array}$ & $\square$ \\
\hline 17. & $\begin{array}{l}\text { In which of these locations would you prefer to practice upon completion? Rural area [1] } \\
\text { Urban area [2] } \\
\text { Give a reason for your answer ......................... } \\
\text { If your answer is [1], please, move to question } 20\end{array}$ & $\square$ \\
\hline 18. & $\begin{array}{l}\text { In which of the following major cities would you prefer to practice? Cape town [1] } \\
\text { Durban [2] } \\
\text { Johannesburg [3] Pretoria [4] Other (specify) [5] }\end{array}$ & $\square$ \\
\hline 19. & $\begin{array}{l}\text { Do you feel that the South African optometry market is becoming saturated? Yes [1] No } \\
\text { [2] }\end{array}$ & $\square$ \\
\hline 20. & $\begin{array}{l}\text { Considering the private and public sector, which one has greater advantages for a recently } \\
\text { graduated optometrist? } \\
\text { Private [1] Public [2] Give a reason for your choice...... }\end{array}$ & $\square$ \\
\hline 21. & $\begin{array}{l}\text { Do you think that the government offers sufficient opportunities for optometrists? Yes [1] } \\
\text { No [2] }\end{array}$ & $\square$ \\
\hline 22. & $\begin{array}{l}\text { Considering the current economic status in this country, what do you think should be the } \\
\text { minimum salary for a newly qualified optometrist in the following settings? } \\
\text { Public sector R Private sector R }\end{array}$ & \\
\hline 24. & $\begin{array}{l}\text { Personally, do you think it is right for optometric practices to advertise through the media } \\
\text { such as TV, radio, magazines and newspapers? Yes [1] No [2] } \\
\text { Give a reason for your choice............................... }\end{array}$ & $\square$ \\
\hline 25. & $\begin{array}{l}\text { Do you think the public is educated enough about optometry, to be able to appreciate the } \\
\text { true value of advertised offers such as 'buy one get one free'? } \\
\text { Yes [1] No [2] }\end{array}$ & $\square$ \\
\hline 26. & $\begin{array}{l}\text { Do you feel that continuing Professional development (CPD) activities will enhance your } \\
\text { professional activities? Yes [1] No [2] }\end{array}$ & $\square$ \\
\hline 27. & $\begin{array}{l}\text { What type of CPD activity would you prefer to participate in: Lectures [1] internet [2] } \\
\text { conference attendance [3] writing research articles [4] Presenting papers or posters at } \\
\text { conferences [5] Others state.............. [6] } \\
\text { Make } 3 \text { choices in order of preference. }\end{array}$ & $\begin{array}{l}\square \\
\square \\
\square\end{array}$ \\
\hline 28. & $\begin{array}{l}\text { Which of the following benefits do you think an optometrist should get when employed in } \\
\text { an existing practice? Select THREE in order of preference from the following options: Life } \\
\text { insurance [1] Medical aid [2] Subscription to professional organizations [3] Vacations [4] } \\
\text { Assist in acquiring CPD points [5] Other (specify please)............................ }\end{array}$ & $\begin{array}{l}\square \\
\square \\
\square\end{array}$ \\
\hline 29. & $\begin{array}{l}\text { Did you at any time during your optometry studies felt that you should have studied another } \\
\text { course rather than optometry? Yes [1] No [2]. If your answer is Yes, state the course... }\end{array}$ & $\square$ \\
\hline 30 & $\begin{array}{l}\text { Do you have any plans to leave South Africa and practice overseas? Yes } \\
\text { If your answer here is NO, move to question } 33\end{array}$ & $\square$ \\
\hline
\end{tabular}




\begin{tabular}{|c|c|c|}
\hline 31 & $\begin{array}{l}\text { If your answer to question } 30 \text { is yes, what is the probable duration? Short time (2 years or } \\
\text { less) [1] } \\
\text { Long time (3-10 years) [2] Permanently [3] } \\
\text { Cannot decide duration yet [4] }\end{array}$ & \\
\hline 32 & 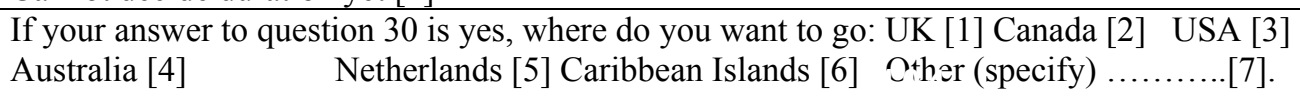 & \\
\hline 33 & What is your greatest concern for optometry in South Africa? & \\
\hline 34. & $\begin{array}{l}\text { On a scale of } 1-10 \text { (where } 1 \text { is very negative and } 10 \text { is very positive), what is your } \\
\text { perception of the future of optometry in South Africa? }\end{array}$ & \\
\hline 35. & $\begin{array}{l}\text { What speciality interests in optometry would you like to pursue? Binocular vision [1] } \\
\text { Contact lenses [2] Low vision [3] Pediatric optometry [4] Sports vision [6] Others stat[7] }\end{array}$ & L \\
\hline
\end{tabular}

Thank you for completing the questionnaire. 